\title{
An Application of Powtoon as a Digital Medium: Enhancing Students' Pronunciation in Speaking
}

\author{
Asni Syafitri ; Abdul Asib; Sumardi Sumardi \\ Universitas Sebelas Maret, Indonesia \\ Email: asni.syafitri@gmail.com
}

http://dx.doi.org/10.18415/ijmmu.v5i2.359

\begin{abstract}
This research is focused on the use of Powtoon as a digital medium to improve the students' pronunciation in speaking class. The researcher applies a classroom action research which consists of two cycles with three meetings in every cycle. Collections of quantitative and qualitative data are gained from test, observation, questionnaire, interview, and diary. The quantitative data obtained from the test are analyzed in order to find out the mean score. Furthernore, the qualitative data are analyzed by: assembling the data, coding the data, comparing the data, building interpretations, and reporting the outcomes. The result of the research shows that Powtoon as a digital medium could improve: 1) the students' pronunciation in speaking class; and 2) the students' learning motivation. Hence, the findings reveal that improving the students' pronunciation in speaking using Powtoon was successful viewed from some dimensions. The implementation of using Powtoon improved the teaching and learning process in speaking. The motivation, attention, interest and participation of the students improved. Therefore, it is recommended for teachers to use Powtoon in teaching speaking especially when they want to improve students' pronunciation and to improve students' motivation in the speaking class.
\end{abstract}

Keywords: Classroom Action Research; Powtoon; Pronunciation; Speaking

\section{Introduction}

According to Cameron (2001: 40), speaking is the active use of language to express meaning so that the other people can make sense of them. Bailey (2005: 2) says that speaking is the productive oral skill, which consists of producting systematic verbal utterances to convey meaning. It means that speaking consists of producing systematic verbal utterance to convey meaning which make other people understand what we are talking about clearly. Moreover, Fulcher (2003: 23) states that speaking is the verbal use of anguage to express ideas, opinion, and feelings.

Based on several definitions above, it can be concluded that speaking is an interactive activity to construct meaning through the process of producing, receiving, and processing information in order to express ideas, opinion, and feelings by using verbal and non verbal symbol or uttarance depending on the context, participant, experience, environtment, and purpose. 
Pronunciation is a part of speaking component that concern on how human pronounces the word and perceives the sound. As a sub skill of speaking, pronunciation has the prominent factor in English as a Foreign Language, especially in communication. Communication can happen if there is a relation between speaker and hearer. In speaker utterance, she/he should comprehend in what she/ he hears in the target language and can produce the sounds in the language that she/ he has been learned accurately. When she/he can produce the correct pronunciation, the hearer in target language can receive it well and the communication between both of them can be maintained. In other word, pronunciation is one of great importance for successful oral communication to take place since it is an important ingredient of the communicative competence.

In fact, some students feel difficult to speak English appropriately and acceptably. There are lots of students who can write but cannot speak up. The students still have low pronunciation. Many students speak incorrectly. The students were still afraid of making mistakes and afraid their words or sentences could not be understood by the teacher or their friends. It will be a big problem for the students in pronouncing words. Consequently, they will not be able to understand English completely especially in speaking.

On Saturday, March $5^{\text {th }} 2016$, the researcher conducted a preliminary study at SMAN 8 Surakarta. From the preliminary research, the researcher found that the students still have difficulties in pronouncing words. The students have less confidence because they were afraid of making mistakes.

The problem above could be caused by the teacher, the students, and the teaching learning process. There causes from the teacher were: 1) the teacher gave less portion of teaching pronunciation than other sub-skills of speaking; and 2) the teacher did not use appropriate media to teach pronunciation; and 3) the teacher focused more on acquiring the other skills such as reading and writing rather than speaking. Considering this situation, the researcher is interested in conducting this study to improve students' pronunciation in speaking.

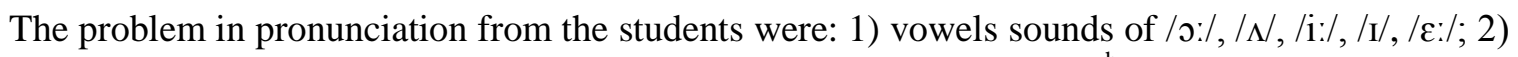

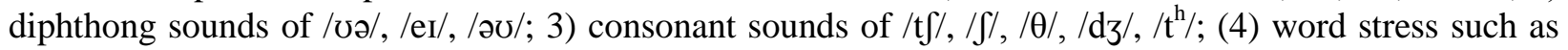
the word such department /di'pa:t.mənt/, accessories /ək'ses.ər.is/, tomorrow /tə'mbrəo/, mountain /'maontın/, and beneath /bi'ni: $\theta /$; and 5) Intonation. In addition, the causes from the teaching learning process was the time allocation for teaching speaking in this school is not sufficient since most of the time is used for teaching other skills focusing on National Examination preparation.

The English teaching learning process in SMAN 8 Surakarta focuses more on acquiring the other skills. The teacher thought that speaking is complicated since it needs a long process. Automatically, the frequency of teaching pronunciation in speaking is decreasing. The condition influences the quality of the students' pronunciation in speaking skill. In addition, in teaching learning process in SMAN 8 Surakarta, the students learn speaking without using a good approach and treatment. The teaching learning process focuses on the text in the students' work sheet.

Moreover, from the teacher's side, there was still teacher-centered in teaching and learning process, the teacher gave little exercise to the students to practice and increase their speaking performance in the classroom and she also still used a traditional method (drilling) in teaching and mostly without using media. The teacher also rarely uses media which help them to pronounce well. Finally, the class condition was quite boring. It could be seen from the students' motivation and the monotonous teaching and learning process without any audio and visual aids.

The researcher discovered that the students are lack of speaking strategies. They have limited knowledge about pronunciation in speaking, including segmental and suprasegmental features. Dealing 
with these problems, the students need media that can help them how pronounce words appropriately and acceptably. One of the media that can be used in teaching pronunciation is Powtoon. Powtoon can be a medium to help students to pronounce words appropriately and acceptably.

\subsection{Structure}

a. Based on the Result of the Preliminary Research During Peer Teaching and Learning Process in the Classroom, the Problems in Pronunciation Were Described, as Follows:

\section{1) Vowels}

There are some difficulties when they pronounce vowel such as the word store /sto:/ is pronounced as " $\mathbf{p}$ " instead of " $\mathbf{v}:$ :; the first syllable of the word color /'kılə/ is pronounced as "o", instead of " $\boldsymbol{\Lambda}$ "; the word need /ni:d/ is pronounced as "I", instead of "i:"; the word will /wil/ is pronounced as "ai", instead of "I".

\section{2) Diphthongs}

There are some difficulties when they pronounce diphthong such as the first syllable of the word poor /pvə/ is pronounced as " $\boldsymbol{~}$ " instead of " $\boldsymbol{\sigma ə}$ "; the word take /terk/ is pronounced as "I", instead of "eI";

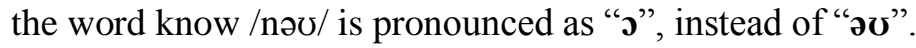

\section{3) Consonants}

There are some difficulties when they pronounce consonant such as the word watch /wpt $\int /$ is pronounced as " $t$ " instead of "t $t$ "; the word flash /flaf/ is pronounced as "s" instead of " $\int$ "; the word think

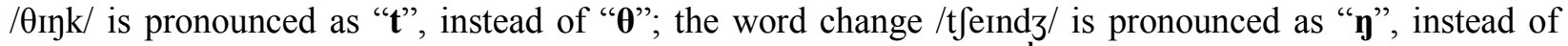
"dz"; the word anytime /'en.i.tarm/ is pronounced as " $t$ ", instead of " $t$ "h".

\section{4) Word Stress}

There are many students speak without having regard to the stress pattern such as the word such department /di'pa:t.mənt/, accessories /ək'ses.ər.is/, tomorrow /tə' mprəo/, mountain /'maontın/, and beneath /bi' ni: $\boldsymbol{\theta} /$. They pronounce the words without stress pattern.

\section{5) Intonations}

In speak english, students only focus on sounds in every word without regard to intonation in the words spoken. For examples: a) You are going; b) You are going?.

\section{b. Benefits of the Study}

For students, Powtoon as a digital medium can provide useful media for the students to grasp the material easily. The students can enjoy with this media to improve their learning motivation and pronunciation in speaking. 
For teachers, this study provides teachers media which can be applied in their teaching learning process to improve the quality of teaching. Using this media, teachers can give the innovation in delivering the material to the students and help them solve the problems of improving the students' learning motivation and the students' pronunciation. In addition, the result of this research can be used as reference for the teacher who wants to solve the problem in improving students' pronunciation.

For other researcher, hopefully, this study provides some information dealing with teaching pronunciation using Powtoon as a digital medium. The result of this research can be utilized to conduct the same and further research on bigger scope.

\section{c. The Researcher Formulates the Following Problems}

1) How is Powtoon as a digital medium able to enhance the students' pronunciation?

2) How is Powtoon as a digital medium able to enhance the students' learning motivation to speak in English in teaching speaking?

\section{d. The objectives of This Research Are}

1) To reveal the improvement of students' pronunciation when the teacher uses Powtoon as a digital medium in teaching speaking

2) To describe the students' learning motivation when the teacher uses Powtoon as digital medium in teaching speaking

\section{Related Works/Literature Review}

\subsection{Pronunciation}

\section{a. The Nature of Pronunciation}

Pronunciation is a key aspect in the development of oral skills. Proper pronunciation is inherent to any competent speaker but this competence can be trained in any non-native speaker. It is viewed as a sub-skill of speaking. Pronunciation is the act or manner of pronouncing words; utterance of speech. In other words, it can also be said that it is a way of speaking a word, especially a way that is accepted or generally understood. In the senses, pronunciation entails the production and reception of sounds of speech and the achievement of the meaning (Kristina., Diah., et al., 2006: 1). It contains some important keys in pronunciation: act, speaking, production and reception of sound. It means that the words being pronounced should be understandable.

Fraser (2000a: 7) explains that being able to speak English includes a number of sub-skills of which pronunciation is by far the most important (other sub-skills of speaking include vocabulary, grammar, and pragmatics). She argues that "with good pronunciation, a speaker is intelligible despite other errors; with poor pronunciation understanding a speaker will be very difficult, despite accuracy in other areas". Pronunciation has many features as shown in Figure 1. 

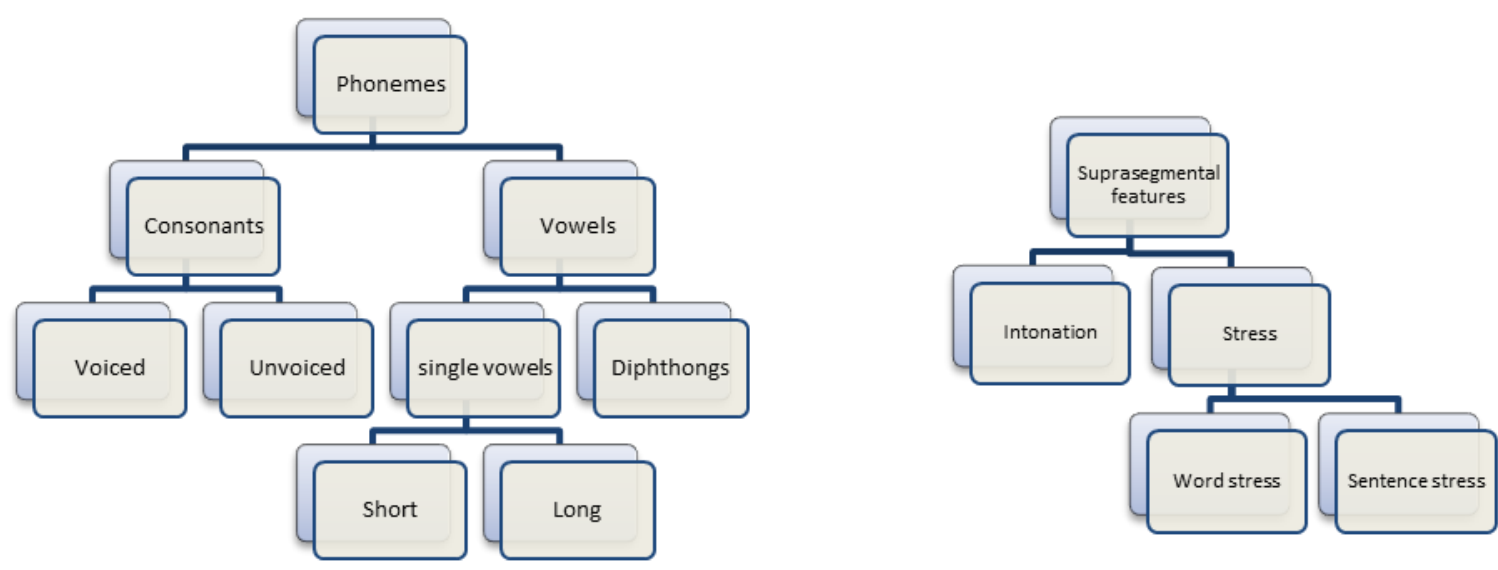

Fig. 1 Features of pronunciation (Kelly., 2000: 1)

Furthermore, explanation of the Figure details are:

\section{1) Phonemes}

Phonemes are different sounds within a language. It is also known as a segmental phoneme feature. Kelly (2000: 1) states that although there are slight differences in how individuals articulate sounds, we can still describe reasonably accurately how each sound is produced. When considering meaning, we see how using one sound rather than another can change the meaning of the word. It is this principle which gives us the total number of phonemes in a particular language. For example, the word rat has the phoneme/ræt/.

Sounds maybe voiced or unvoiced (sometime referred to as "voiceless). Voiced sounds occur when the vocal cords in the larynx are vibrated. It is easy to tell whether a sound is voiced or not by placing one or two fingers on your Adam's apple. If you are producing a voiced sound, you will feel vibration; if you are producing an unvoiced sound, you will not. The difference between /f/ and /v/, for example, can be heard by putting your top teeth on your bottom lip, breathing out in a continuous stream to produce $/ \mathrm{f} /$ then adding your voice to make /v/. Hold your Adam's apple while doing this, and you will feel the vibration.

Phonemes can be grouped into two categories those are vowel sound and consonant sound. Vowel sound are all voiced, may be single (like /e/, as in let), or a combination, involving a movement from one vowel sound to another (like /eI/, as in late); such combination are known as diphthongs. An additional term used is tripthongs which describes the combination of three vowel sounds (like /avə/ in our or power). Single vowel sounds may be short (like /I/, as in hit) or long (like /i:/, as in heat). The symbol /:/ denotes a long sound.

Consonant sounds may be voiced or unvoiced. It is possible to identify many pairs of consonants which are essentially the same except for the element of voicing (for example /f/, as in fan, and /v/, as in van). The following table list English phonemes, giving an example of a word in which each appears.

In segmental phoneme, syllable is stand on the concept of vowel and consonant. Based on Kreidler's (2004) explanation that syllables in sequence differ in intensity (or loudness), in pitch (or tone), 
and in duration-some syllables are comparatively strong and others are weak. Syllable strength depends on several things: what vowel it has, whether it is the stressed syllable of a word, and whether it is the accented syllable of a tone unit. It deals with the structure of English syllables and the patterns of strong and weak syllables in words and in tone units. Every English word consists of at least one syllable, and many words have two, three, four, or more syllables. The syllable is a unit that is hard to define with scientific rigor but fairly easy to recognize. Anyone can tell the number of syllables in, for example, cat, delay, wonderful, geography, and metamorphosis. Every syllable has a structure, a sequence of some of

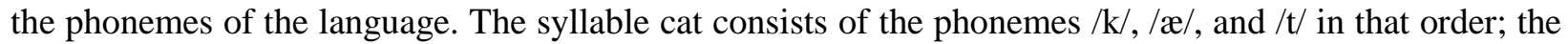
syllables act and tack have the same three phonemes but in different sequences. Initial syllable is a syllable in front of the word that will be sound first. For example, the word three, the initial syllable is $/ \theta /$ that sounds in the beginning of the word. Ending syllable is a syllable in the end of the word that will be sound lastly. For example, the word eleven, the ending syllable is /t/ that sounds in the end of word. Different languages have different kinds of syllable structure. Describing the possible syllable structures is part of describing the sound system of a language.

\section{2) Suprasegmental Features}

Kelly (2000: 3) explains that suprasegmental features are features of speech which generally apply to group of segments or phonemes. The features which are important in English are stress, intonation, and how sounds change in connected speech.

With regard to individual word, we can identify and teach word stress. Usually one syllable in a word will sound more prominent than the others, as in PAper, or BOttle. The stress in words are usually indicated in dictionaries. With regard to utterances, we can analyze and teach intonation as well as stress, although as features they can at times be quite hard to consciously recognize and to describe. Stress gives rhytm to speech. One or more words within each utterance are selected by the speaker as worthy of stressing, and thus made prominent to the listener. Intonation, on the other hand, is the way in which the pitch of the voice goes up and down in the course of an utterance.

When discussing speech the term utterance is used rather than "sentence", as it refers to anything we say including grammatically incomplete sentences, and to different ways of saying the same sentence.

Utterance stress and intonation patterns are often linked to the communication of meaning. For example, in the following utterance the speaker is asking a question for the first time. In this particular instance as you can hear on the $\mathrm{CD}$, pitch of her voice starts relatively high and falls at the end, finishing relatively low.

Linking means making words sound connected, and it is a normal part of English pronunciation. Linking is the reason why many frequently-used short phrases, end up sounding like one big word, such as: What time is it?, How is it going?, Come on in!.

From the explanation above, it can be concluded that in learning pronunciation cannot be ignored the segmental phoneme and suprasegmental features. Both of features have important pattern in pronunciation proficiency. When we learn about segmental phoneme, the suprasegmental will follow it. Getting better in pronouncing the word or sentence should be accompanied by the use of segmental phoneme and suprasegmental. In learning pronunciation, students should master some indicators those are pronouncing certain initial syllable, pronouncing certain ending syllable, pronouncing the name of the things in the picture in correct word stress, using appropriate intonation in telling simple sentence, and pronouncing linking word in simple sentence. 
However, based on the research problem, the researcher limited the problem of the study in segmental and suprasegmental phoneme. In learning pronunciation, students should understand some indicators those are; 1) vowel (long vowel, short vowel, and diphthong); 2) consonant (voiced consonant and unvoiced consonant); 3 ) word stress; and 4) intonation.

\section{b. The Indicators in Pronunciation}

Pronunciation is a part of speaking component that concern on how human pronounces the word and perceives the sound. As a sub skill of speaking, pronunciation has the prominent factor in English as a Foreign Language, especially in communication. Communication can happen if there is a relation between speaker and hearer.

The features of pronunciation are segmental phoneme and suprasegmental features. In phonemes, there are consonants and vowels and in suprasegmental feature there are stress and intonation.

\section{1) Consonants}

Consonant sounds may be voiced or unvoiced. It is possible to identify many pairs of consonants which are essentially the same except for the element of voicing (for example /f/, as in fan, and /v/, as in van). Based on the problem of the students' pronunciation especially in pronouncing the consonant in word, there are some difficult words such as watch, think, anytime, change and taught. In this research, the researcher focuses on the sound of consonants: $/ \mathrm{t} /, / \mathrm{J} /, / \theta /, / \mathrm{d} 3 /, / \mathrm{t}^{\mathrm{h}} /$.

\section{2) Vowels}

Vowel sounds are all voiced, and may be single (like /e/, as in let), or a combination, involving a movement from one vowel sound to another (like /eI/, as in late); such combination is known as a diphthong. Based on the problem of the students' pronunciation especially in pronouncing the vowel in words, there are some difficult words such as store, color, need, will, hairpin, poor, take and know. In this research, the researcher focuses on the sound of vowels: /s/, /L/, /i:/, /I/, / $\varepsilon$ :/, /və/, /eI/, /əv/.

\section{3) Word Stress}

Syllable and word stress are interrelated. Syllable helps us to provide pressure while practicing English. When there is more than one syllable, the speakers have to know where they will put the pressure on when speaking English. There are many students speak without having regard to the stress pattern such as the word department/dı'pa:t.mənt/, accessories /ək'ses.ər.is/, tomorrow /tə'mprəo/, mountain /'mauntın/, and beneath /bi'ni: $\theta /$. They pronounce the words without stress pattern. Three types of word syllable stress that focused by the researcher are stress of two-syllable, three-syllable, and four-syllable

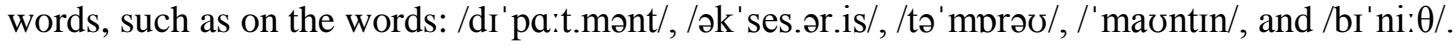

\section{4) Intonation}

Intonation means the rise and decline of voice when talking. In linguistics, intonation pitch variation means you are talking in a way that shows your emotion. In speaking English, students only focus on sounds in every word without regard to intonation in the words spoken. In this research, the 
researcher focuses on three types of the intonation patterns: a) statement, such as "I will take it."; b) yesno question, such as "Is it good for me?"; and c) wh-question, such as "What is it?".

Based on the explanation above, here is the scoring criteria applied in scoring the students' pronunciation.

Table 1 Pronunciation scoring rubric

\begin{tabular}{|c|c|c|c|}
\hline No & Indicator & Score & Description \\
\hline 1 & $\begin{array}{l}\text { Vowels and } \\
\text { Diphthongs }\end{array}$ & $\begin{array}{l}19-24 \\
13-18 \\
7-12 \\
1-6\end{array}$ & $\begin{array}{l}\text { Eight sounds of vowels: } / \mathrm{\partial} /, / \mathrm{\Lambda} /, \mathrm{i}: /, / \mathrm{I} /, / \varepsilon: /, / \mathrm{\jmath} /, / \mathrm{e} /, / \partial \mho / . \\
\text { Test taker is excellent to pronounce seven or all sounds of } \\
\text { vowels. } \\
\text { Two wrong sounds coming from eight sounds of vowels. } \\
\text { Three wrong sounds coming from eight sounds of vowels. } \\
\text { Four wrong sounds coming from eight sounds of vowels. } \\
\text { Five or more wrong sounds coming from eight sounds of } \\
\text { vowels. }\end{array}$ \\
\hline 2 & Consonants & $\begin{array}{l}25-30 \\
19-24 \\
13-18 \\
7-12 \\
1-6\end{array}$ & $\begin{array}{l}\text { Five sounds of consonants; } / \mathrm{t} /, / \mathrm{J} /, / \theta /, / \mathrm{d} z /, / \mathrm{th} / \\
\text { Test taker is excellent to pronounce five sounds of } \\
\text { consonants. } \\
\text { One wrong sound coming from five sounds of consonants. } \\
\text { Two wrong sounds coming from five sounds of } \\
\text { consonants. } \\
\text { Three wrong sounds coming from five sounds of } \\
\text { consonants. } \\
\text { Four or more wrong sounds coming from five sounds of } \\
\text { consonants. }\end{array}$ \\
\hline 3 & tress & $\begin{array}{l}16-20 \\
11-15 \\
6-10 \\
1-5 \\
\end{array}$ & $\begin{array}{l}\text { Three types of word syllable stress are stress of two- } \\
\text { syllable, three-syllable, and four-syllable words, such as } \\
\text { on the words: /dI'pa:t.mənt/, /ək' ses.ər.is/, /tə'mprəo/, } \\
\text { /'maontrn/, and /bI'ni: } \theta / . \\
\text { Test taker is excellent to pronounce all those types of } \\
\text { word stresses. } \\
\text { One mistake out of those types of word stresses. } \\
\text { Two mistakes out of those types of word stresses. } \\
\text { Three mistakes out of those types of word stresses. }\end{array}$ \\
\hline 4 & Intonation & $\begin{array}{l}11-15 \\
6-10\end{array}$ & $\begin{array}{l}\text { Three types of the intonation patterns: } \\
\text { (a) statement, such as "I will take it."; (b) yes-no question, } \\
\text { such as "Is it good for me?"; and (c) wh-question, such as } \\
\text { "What is it?". } \\
\text { Test taker is excellent to pronounce all those types of } \\
\text { intonation patterns. } \\
\text { Test taker is good to pronounce those types of intonation } \\
\text { patterns. } \\
\text { Test taker is fair to pronounce those types of intonation } \\
\text { patterns. } \\
\text { Test taker is poor to pronounce those types of intonation } \\
\text { patterns. }\end{array}$ \\
\hline
\end{tabular}




\subsection{Media for Teaching Speaking \\ a. The Nature of Media}

According to Schramm (1997) in Suwarno, media is a technology that distributes the message to be used in teaching and learning process. Then, Sadiman (1986) defines that media is everything that can be used to provides messages from a deliverer to a receiver; thus it is able to stimulate feelings, minds, cautions and students' interest. To make the explanation clearly, Horby also states that media is the main ways the large number of people receive information and entertainment (2000: 976).

Media is a tool for language teaching and learning which can give a contribution to the teaching learning process. It can be used to increase and improve students' ability in learning English especially in speaking. In this case using media in delivering the lesson can be a good solution. Besides, teaching speaking by using media is important because the students can more easily catch the lesson and be more active in joining the class. It also can motivate and arouse the students' interest in learning English.

Media can be divided into three kinds of media, such as graphical media, audio-media, projective media (Suwarno., 2006: 134). The brief explanation of such kinds of media:

\section{Graphical Media}

Graphical media is a media that relates messages in the form of verbal communication symbols. The examples of graphical media are picture/photography, diagram, poster, map, etc.

\section{Audio-Media}

This kind of media uses verbal and non-verbal auditory message symbols. A radio and tape recorder belongs to audio-media.

\section{Projective Media}

Projective media has several similarities with graphical media. One of the similarities is to be able to present visual stimulation.

Multimedia is a tool that can be used by teachers to enhance pronunciation learning process. Teachers can insert sound, text, pictures, animations, graphics and they have changed the way of teaching and learning the second language. Abbas (2012: 57) defined multimedia as "any computer-mediated software or interactive application that integrates text, color, graphical images, animation, audio sound, and full motion video in a single application".

In teaching and learning process, media has several significances. According to Kemp and Dayton (1985) in Suwarno, the significance of using media in teaching and learning process as follows:

a. When transferring teaching material, it can be showed concurrently. Thus, the learner will pay sufficient attention in one focus in one media.

b. Using media can make the teaching and learning process more interesting to the learners

The learners will be more attractive when the teacher uses an interesting media in the classroom. It can improve the students' positive attitude in learning process. 


\section{b. Digital Media}

There are a variety of ways digital audio can be used in instruction, including: lectur recordings, music, historical recordings or speeches, narration for slides and animations, language training (both for listening and recording).

Digital media: audio, video, and images that exist in a computer-readable format, and can reside on a local device (CD, DVD, hard drive), or remote location (website).

In many ways, digital media are no different from analog recorded media, which have been around for decades. What is unique is the ability to easily create, copy, and transmit digital media. They can be streamed, downloaded, or stored on media such as CD or DVD. The recent popularity of mobile devices such as iPods that allow audio and video to be downloaded and experienced anywhere, anytime, have also increased the use, as well as the hype, around digital media.

While audio and video have a long history of use in education, the capabilities of digital media, coupled with reduced computing costs, higher bandwidth, easier-to-use technology, and greater awareness of digital media have increased their use in education, especially during the last five years. If nothing else, the quote from Thomas Edison above should serve as a reminder that we need to look beyond the excitement of the moment and carefully assess the value of any tool we consider for teaching and learning.

This brief will review some of the more common instructional uses and new technology surrounding the following subset of digital media:

1. Video (including lectures, instructional video, original content)

2. Audio (including podcasts and audio with visuals, e.g., powerpoint)

3. Animations and simulations (e.g., flash content)

This document will discuss unidirectional forms of digital media communication, and therefore will not discuss in detail two-way technology such as video conferencing or web-based seminars that include voice, text chat, etc. We will leave those for another brief.

When digital media is used for visual information, combining the visuals with an audio recording of the speaker can be a very effective technique for capturing presentations - more effective than video in situations where the visual component of video does not contain important information (Clark \& Mayer., 2003; Nielsen., August 2005; Shank., 2005). Visuals are synchronized with the audio and the whole presentation is controllable by the student (play, pause, rewind).

Digital media is a computer tool for creating on-screen multimedia presentations or overhead transparencies. The program helps prepare an outline, slides, speaker's notes and handouts for the audience. Even though this tool was developed for business presentations, it is found that it is useful in the language classroom. Some aspects that are interest in digital media; keep it simple, short and visual; use it to play a game, to start a discussion and to analyze a process or situation. 


\subsection{Powtoon}

In a monolingual country like Syria, English is used and taught as a foreign language and young learners lack the motivation and desire to learn English. Using traditional method in the teaching and learning process makes the teacher the central figure in the classroom which in turn, creates a passive, explicit and de-contextualized language instruction setting which is viewed by Pinter (2006) as inappropriate for the pedagogical needs of young learners. Therefore, many methods, techniques, songs and visuals are used in the classroom for teaching English to ensure motivation and learning of English and to sustain it even outside the classroom. Lin (2009) affirms that the use of the high-powered multimedia (like animations) keep the learner close to authentic situations where learning simultaneously involves listening, watching, reflecting, doing and participating. In this way, animations would address the 5 senses of the young learners and thus attract their attention and keep them involved for a longer period of time and they can be considered as pedagogically valuable sources of language input which can be used inside or outside the classroom as long as they are relevant to the point or have been designed with a specific pedagogical purpose in mind and levelled carefully to the linguistic and cognitive development of young learners.

One of the animation programs used for this concern is PowToon (www.powtoon.com). It is a web-based animation software that allows teachers to quickly and easily create animated presentations by manipulating pre-created objects, imported images or videos, provided music and user created voiceovers making the teaching- learning process more engaging and enjoyable for young learners. For my class of 6-year old students who are learning English in their Beginner level, I have designed my own animation through PowToon to include video songs, colourful images, and video elements like pausing, replaying, and going backwards around one concept which is introducing colours to young learners as vocabulary and their syntactical use as adjectives in different English language utterances through exercises and songs embedded within PowToon animation.

\subsection{Motivation}

Gardner and Lambert (1972: 98) divided motivation into four kinds; they are intrinsic motivation, extrinsic motivation, instrumental motivation, and integrated motivation. The explanation about the four kinds motivation are as follows:

\subsubsection{Intrinsic Motivation}

Ur (1996: 276) states that intrinsic motivation is the motivation that comes from inside the learners. It means the urge to engage in the learning activity. Through this motivation, the learners try to be actively involved in the learning activity. Intrinsic motivation occurs when students are internally motivated to do something because it brings them pleasure. They think that what they do is essential for their lives, or they feel that what they learn is significant.

In line with Ur, Kumaravadivelu (2006: 40) states that intrinsic motivation is the desire to engage in activities characterized by enjoyment. There is no apparent reward except the experience of enjoying the activity itself. He adds that true enjoyment accompanies the experience of what he calls flow, that peculiar, dynamic, holistic, sensation of total involvement with the activity itself.

Gilakjani (2012: 9) states that intrinsic motivation refers to the motivation to engage in an activity because that activity is enjoyable and satisfying to do. Furthermore, Pelletier (2005: 35) states that intrinsic motivation refers to engaging in an activity purely for the pleasure and satisfaction derived from 
doing the activity. When a person is intrinsically motivated, he or she will perform the behavior voluntarily in the absence of materials rewards or external constraints. In more details Pelletier (2005: 36) explains that there are three types of intrinsic motivation. They are:

\section{a) Intrinsic Motivation to Know}

This type of IM relates to several constructs such as exploration, curiosity, learning goals, IM to learn, and the epistemic need to know and understand. Thus, it can be defined as performing an activity for the pleasure and the satisfaction that one experiences while learning, exploring, or trying to understand something new.

\section{b) Intrinsic Motivation Toward Accomplishment}

This second type of IM can be defined a engaging in an activity for the pleasure and satisfaction experienced when one attempts to accomplish or create something.

\section{c) Intrinsic Motivation to Experience Stimulation}

IM to experience stimulation occurs when someone engages in an activity in order to experience stimulating sensation (e.g. sensory pleasure, aesthetic experience as well as fun and excitement) derived from one's engagement in the activity.

\subsubsection{Extrinsic Motivation}

Extrinsic motivation is motivation derived from external incentives (Ur., 1996: 276). The motivation comes from outside the learners such as praise and reward from others. Extrinsic motivation takes place when a student is compelled to do something because external factor that motivates him to do it (for example for the sake of money or good grades).

Furthermore, Kumaravadivelu (2006: 40) states that extrinsic motivation can be triggered only are external cues that include gaining and maintaining peer, sibling, or adult approval, avoiding peer or sibling or adult disapproval, and gaining or losing specific tangible rewards. It is conditioned by practical consideration of life with all its attendant, sense of struggle, success, or failure. Thus, extrinsic motivation is associated with lower levels of self-esteem and higher levels of anxiety compared to intrinsic motivation.

Gilakjani (2012: 9) states that extrinsic motivation pertains to a wide motivation to engage in activity because of certain reason, such as achieving some instrumental end, earning a reward or avoiding a punishment. Pelletier (2005: 36) states that extrinsic motivation pertain to a wide variety of behaviors that are engaged in as means to and end not for their own sake. It is originally thought that extrinsic motivation refers to non-self-determined behavior, behavior that could only be prompted by external contingencies (e.g. rewards). In more detail, Pelletier (2005: 37) states that there are also three kinds of extrinsic motivation. They are: 


\section{a) External Regulation}

This type of motivation refers to behavior that is controlled by external sources, such as material rewards or constrains imposed by others.

\section{b) Introjection}

Introjection, the formerly external source of motivation has been with internalized such that its actual presence is no longer needed to initiate behavior. Instead, these behaviors are reinforced through internal pressures such as guilt or anxiety.

\section{c) Identification}

This last type of extrinsic motivation is in operation when the individual comes to value and judge the behavior as important, therefore performs it is out of choice. The activity is still performed for extrinsic reasons (e.g., to achieve personal goals); however, it is internally regulated and self-determined.

\subsubsection{Instrumental Motivation}

Gardner and Lambert (1972: 98) explains that instrumental motivation refers to an interest in learning L2 for functional purposes such as getting a job or passing an examination. Gilakjani (2012: 9) explains that instrumental motivation is regarded motivation as arising out of a need to learn the L2 for functional or external reasons. These include the achievement of goals, utilitarian purposes for learning such as passing exams, financial rewards, furthering a career, or gaining promotion.

\subsubsection{Integrative Motivation}

Most studies on motivation have been inspired by the distraction social psychologists Gardner and Lambert (1972: 98) made between integrative and instrumental motivation. Integrative motivation refers to an interest in learning an L2 in order to sociocultural integrate with members of the TL community. Instrumental motivation refers to an interest in leaning an L2 for functional purposes such as getting a job or passing an examination. In several studies Gardner and Lambert reported that integrative motivation is far superior to instrumental motivation.

Gilakjani (2012: 9) states that integrative refers to language learning for personal growth and cultural enrichment that is the learners' desires to learn a language to integrate successfully onto the target language community. In line with Gilakjani, Pelletier (2005: 35) states integrative motivation is motivation that triggers the learners to become as the member of the target language community. The learners force themselves to learn the target language in order to be involved in the community that has the language.

Noels (2003: 77) proposes a larger motivation construct made up of three interrelated substrates. The first substrate includes intrinsic reason inherent in the language learning process, such as whether learning the language is fun, engaging, challenging, or competence-enhancing. The second category includes extrinsic reason of language learning lying on a continuum of self-determination, including external and internalized pressure. The third substrate comprises integrative relating to positive contact with the L2 group and perhaps eventual identification with that group. 
With regard to examining environmental influences on learner self-determination, Noels and her colleagues found a consistent pattern: the more students perceived their teachers as controlling and as failing to provide instructive feedback, the less they were intrinsically motivated. Thus, perceptions of autonomy support and informative feedback from teachers enhanced the students' feeling of intrinsic motivation.

In language learning orientation, it can be illustrated that intrinsic motivation is the joy of doing particular activity or the feeling of satisfaction after fulfilling one's curiosity. The source of extrinsic motivation is inaccessible to the influence of the teachers: for example the students' desire to please others such as parents or other authority figures. However, other sources are certainly affected by teacher action. Among them are success and its rewards, failure and its penalties, authoritative demand, tests, and competition. Reward can also be organized as extrinsic and intrinsic. Extrinsic rewards are external to the person; for example: praise or money. Intrinsic rewards are internal to the person; for example, satisfaction or a feeling of accomplishment.

Brown (2001: 75) says that motivation refers to the intensity of one's impetus to learn. The intensity of motivation of the learners to retain the goal can be high or low. He states that motivation is divided into two. They are intrinsic and extrinsic. Both designate a continuum of possibilities of intensity of feeling of drive, ranging from deeply internal, self-generated reward to strong, externally administered reward from beyond one self.

Intrinsic motivation is not the main factor to determine success for a language learner. Sometimes you may not succeed for a host of other reasons. But if the learners in your classroom are given an opportunity to do language for their own personal reasons of achieving competence and autonomy, those learners will have a better chance of success than if they become dependent on external rewards for their motivation.

The teacher will not find difficulties in teaching and learning process in the classroom if the students have high motivation but for the low motivation students, it is problem for the teacher as they have difficulties in the learning activity, so it is the duty of the teacher to give suitable motivation for the students.

Based on the theories above, it shows that motivation is an impulse, emotion, initiation, intensity, or desire, direction, and persistence of behavior that arouse one to do particular action and retain one engaged in certain activities to reach the goal of learning. Motivation is strongly related to achievement in learning a language.

Based on the construct above, the researcher can formulate some indicators as follows: 1) students' interest in learning, to motivate the students such as praise and reward from others; 2) students' desire in learning; 3) students' attention in learning; and 4) students' activeness in learning.

\subsection{Review of Related Research}

Here is the review of related research that used in this research as follows:

The first of related research is Abbas Pourhossein Gilakjani (2011) in his journal entitled "a Study on the Situation of Pronunciation Instruction in ESL/EFL Classrooms" that in the journal describe about the status of pronunciation teaching from the viewpoint of many English language teachers, researchers, and writers. Firstly, a brief history of teaching pronunciation and factors affecting the learning of pronunciation are discussed. Secondly, the reason of encouraging students to improve their 
pronunciation and the time of introducing pronunciation will be discussed. Thirdly, the researcher investigates the kind of pronunciation materials and segmental and suprasegmental features. Finally, the article discusses a number of suggestions for teaching pronunciation and indicates that the teaching of pronunciation can be made more effective in the ESL/EFL classrooms.

The second of related research is from Ramdan Nugraha (2014) that conducted her research in Classroom Action Research entitled "Using Digital Presentation in Teaching Speaking". Based on what the EFL teachers directly experienced that teaching speaking using digital presentation is purposively providing the ways to achieve the aims of teaching through the interesting and attractive presentation of teaching learning process. We have to realize that today's learners are extremely familiar to all digital things in their daily life. But, it does not mean that teachers would rely on the digital presentation for the whole of the teaching process as what one of the EFL teachers in this research said. The digital presentation is only a tool to help teachers get an easier way to deliver the materials to their learners.

The last of related research is from Cisco (2011) entitled "Video: How Interactivity and Rich Media Change Teaching and Learning". Video is highly engaging, and with students who are sophisticated consumers, creators, and editors of video content, introducing video-based teaching and learning resources is much easier. Video also opens the world to students through face to-face learning experiences, as they meet students in other school districts, or even in other countries. Schools are using video to bridge time and distance barriers as they expand access to specialized resources, such as honors classes, delivering these courses to qualified students. Teachers gain easier access to teaching strategy, sessions and resources, without the cost and inconvenience of having to travel. Finally, schools are able to work together to create strategies for improving learning and graduation rates. The use of video technology in education is only in the beginning stages, and it holds much promise for improving efficiency, teaching and learning effectiveness, and students' educational outcomes.

Furthermore, Media of teaching has a very important role for effectively helping teachers to deliver materials to students. It is not a main tool that every teacher has to use when they teach, but it could be very useful in order to support the teaching learning process between teachers and student. Pronunciation is a sub-skill of speaking that is often used by many researchers to conduct the research. Here, the researcher used digital media to improve students' pronunciation. Digital media can be used to deliver the teaching material to the students. The relation between the existing researches with this research is using digital media to make students more interested in teaching and learning process. In this research, the researcher wants to give different presentation from the previous researchers. The previous researchers only focus on one media that is used such as video; here the researcher wants to use game, song and video to improve students' pronunciation in speaking. It makes students' interest to learn in different ways. It also makes the teacher deliver the material easily by using digital media.

\section{Material \& Methodology}

\subsection{Data}

In this research, the writer uses qualitative and quantitative methods in collecting the data. The explanation about techniques for collecting data used in this research can be seen as follows:

\section{Qualitative Techniques \\ a. Observation}

The researcher conducts general observation by observing the teaching and learning processes in class XI-Science 4 that happen before, during, and after the implementation of Powtoon as a digital 
medium in the classroom. The data that will be collected by the observation are students' pronunciation and students' motivation in speaking English.

\section{b. Field Notes}

Field notes are used to record activities that happen in the class. It is used to observe the improvement of students' pronunciation skill from their behavior sides. Collaborative observers' notes or field notes are used in this research, so the researcher took a note on important activities relating to students' pronunciation skill and their motivation in speaking English appropriately and acceptably.

\section{c. Interview}

Interviews are face-to-face personal interactions which generate data about the research issue and allow specific issues to be discussed form other people's perspective (Burns., 1999: 117). Interview will be done twice, before and after research. The researcher will interview the English teacher and some students to get information about students' pronunciation in speaking and their motivation in speaking English appropriately and acceptably.

\section{d. Photographs}

Photographs are used to record activities that happened in the class. It happens before, during, and after the implementation of Powtoon as a digital medium in the classroom. It can give real description about teaching learning process.

\section{Quantitative Technique (Test)}

Besides the non-test techniques above, researcher also uses test techniques. A test has the purpose of measurement, as stated by Brown (1994: 252), test is a method of measuring a person's ability or knowledge in a given area. The test techniques are conducted by giving a pre-test before the action begins and a post-test in the end of the action. The pre-test will be held in the beginning of the research before implementing the action or treatment. The post-test will be conducted after implementing the action. The improvement can be seen if the students can reach higher score in the posttest than pre-test. After collecting the data, the next step of the study is analyzing the data. The data are analyzed by using qualitative and quantitative data analyses.

\section{Qualitative}

Analyzing data begins as soon as collecting the data. Burns (1999: 156) gives several steps of constant comparative method that can be used to analyze the qualitative data:

\section{a. Assembling the Data}

The first step the researcher must do is to assemble the data that have been collected over the period of the research, for examples: field notes, journal entries, questionnaires and so on. The researcher can start the initial questions as a starting point to be scanned that began the research. At this stage, broad patterns should begin to show up which can be compared and contrasted to see what fits together. 


\section{b. Coding the Data}

Coding is a process of attempting to reduce the large amount of the data that may be collected to more manageable categories of concept, theme or types. Data analysis becomes much messier and coding becomes less clear cut when it is dealing with diary entries, classroom recordings, or open ended survey questions.

\section{c. Comparing the Data}

After the previous stages has been done, the data must be categorized, and then comparisons can be made to see whether themes or patterns are repeated or developed across different data gathering techniques. The researcher may also be able to map frequencies of occurrences, behaviors, or responses. The main aim at this stage is to describe and display the data rather than to interpret or explain them.

\section{d. Building Interpretations}

In this stage, the researcher tries to describe, categorized, code, and compare to make some sense of the meaning of the data. This stage demands a certain amount of creative thinking as it is concerned with articulating underlying concepts and developing theories about why particular patterns of behaviors, interactions, or attitudes have emerged.

\section{e. Reporting the Outcomes}

The final stage involves presenting an account of the research for others. A major consideration is to ensure that the report sets out the major processes of the research, and that the findings and outcomes are well supported with examples from the data. Then the data is presented in the report. The researcher had provided supporting examples of the data. After the data have been analyzed, they were interpreted to help answer the problems of the research.

This research uses the method stated by Burns (1999: 156) to analyze the data. There are five steps and those steps are clear and sequential. It begins with assembling the data, coding, comparing, and then building interpretations, and finally reporting the outcomes.

\section{Quantitative Data}

In analyzing whether there is any improvement of students' speaking pronunciation in each cycle, the researcher conducts a pre-test and post-test to the students and accounted their scores individually. Then, the students' individual scores are computed using this formula:

Individual score $=\frac{\text { gained score }}{\max \text { score }} \times 100$

After analyzing students' individual scores, then the researcher obtains the mean scores of the pre-test and post-test of each cycle using the following formulas: 


$$
\begin{array}{ll}
- & \quad \text { a. } \mathrm{X}=\frac{\sum x}{n} \\
\overline{\mathrm{X}} & =\text { mean score of pre-test } \\
\sum \mathrm{x} & =\text { total score } \\
\mathrm{n} & =\text { total students } \\
& \quad \text { b. } \quad \mathrm{Y}=\frac{\sum y}{n} \\
\overline{\mathrm{Y}} & =\text { mean core of post-test } \\
\sum \mathrm{y} & =\text { total score } \\
\mathrm{n} & =\text { total students }
\end{array}
$$

The mean of the oral pre-test compare to the mean of the first, second, and third oral post-test to find whether the students' speaking pronunciation improve or not. Finally, the researcher makes a conclusion based on the data analysis. If the mean score result increases, the students' speaking pronunciation considers improving and the research is successful.

\subsection{Methodology}

This research used action research as the method. According to Kemmis and McTaggart (1988) in Nunan (1992: 17), there are three characteristics of action research; 1) the action research is carried out by practitioners rather than outside practitioners; 2) The action research is collaborative; and 3) the action research is aimed at changing condition. There are some definitions of Action Research proposed by some experts. According to Bogdan and Biklen (in Burns., 1999: 30), "action research is the systematic collection of information that is designed to bring about social change."

Hopkins (1993:1) states that "action research is an act undertaken by teachers, to enhance their own or colleague's teaching, to test the assumption of educational theory in practice, or as a means of evaluating and implementing whole school priorities". Nunan (1992: 18) also argues that action research has a distinctive feature that is affected by planned changes have the primary responsibility for deciding on course of critical informed action in which seem likely to lead to improvement, and for evaluating the result of strategies tried out in practice.

Supporting the idea Burn (1999) says that Action Research has some features characteristics as follows: first, Action Research is contextual, small scale, and localized. It identifies and investigates problem within a specific situation; second, it is evaluating and reflecting the aim to bring a changing and improvement in practice; and the next is Action Research provides collaborative investigations by teams of colleagues, practitioners and researchers; the last is it changes the practice based on the collection information which provide the impetus of changing.

From the definition above, it can be concluded that action research is systematic collection and analysis of data to get practical problem solving in social situation that is done by researcher to improving and evaluating the results of strategies practiced. These are the reason why the writer use action research in conducting the problem appeared in teaching English during the teaching and learning process in the classroom. The purpose of the research is to enhance students' motivation in learning English and give best solution for the problem. 


\section{Results and Discussion 4.1.Result}

The researcher divided the findings into two aspects: students' pronunciation in speaking and students' learning motivation.

\subsubsection{The Progress Students' Pronunciation in Speaking}

The result of this research shown that the the implementation of Powtoon could develop students' pronunciation in speaking. It can be seen from the students' score of the test. The mean score of pre test was 61.65 , and it increased on the first post test into70.23, then it increased again on the second post test into 74.05. From those scores, the researcher ran a t-test to see whether significant difference exists in this study. The calculation shows that the t-test value was statistically greater than the t-table value.

\subsubsection{The Students' Learning Motivation}

The result of observation from pre-research to second cycle showed that students' motivation improved. The class situation was more alive. They looked motivated in learning. Students were interested in following the class. They were more active during teaching and learning process, moreover if they watched the material that showed in Powtoon. This is in line with Harmer (2001: 282) who states that most students show an increased level of interest when they have a chance to see language in use as well as hear it, and when this is coupled with interesting task. It is a visual stimulus; learners hear authentic language used in context. The combination of moving picture and sound can present language more comprehensible than any other teaching medium. Its visual aspect facilitates comprehension. Besides, Dewi and Junaedi (2011: 5) state that the setting, action, emotions, gestures in a video provides an important visual stimulus for language production and practice.

\subsection{Statement of Results}

\subsubsection{The Progress Students' Pronunciation in Speaking}

As mentioned before, the focus of this research is on pronunciation in speaking development. The result of pre test, post test 1 , and post test 2 show that the students' pronunciation developed. The pronunciation itself covers two aspects namely segmental (vowel, diphthong, consonant) and supra segmental features (word stress and intonation). The development of students' pronunciation can be seen in the chart on the next page.

\subsubsection{The Students' Learning Motivation}

In addition, the appropriate activities during the teaching and learning process also take important role towards students' motivation. The students had different activity in cycle 1 and cycle 2 . In cycle 1 , the final activity of students was performing to sing a song and they could perform it well. In cycle 2, the final activity was a bit different from cycle 1 . Here, the students were asked to perform their dialog. It meant that they had to work with their friend, on the other words, they worked in pair. Having such a kind of activity, the students looked more motivated in teaching and in learning process. When performing the dialog, they looked more confident and could practice the dialog better. 


\subsection{Explanatory Text}

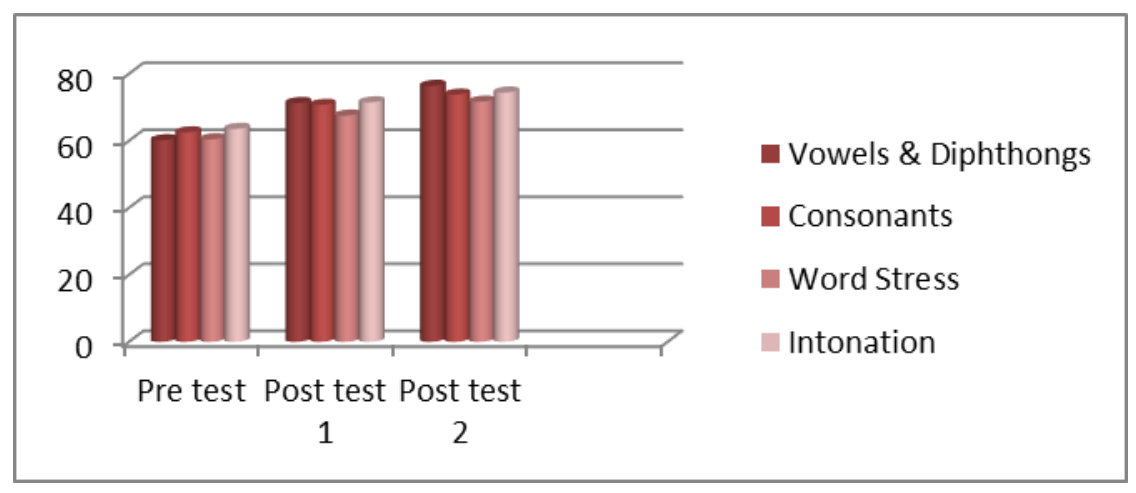

Fig. 2 The Development of Students' Pronunciation in Speaking

Table 2 Comparison of students' motivation in pre-observation and Cycle 1

\begin{tabular}{|c|c|c|}
\hline Indicator & Observation in Cycle 1 & $\begin{array}{l}\text { Observation in Cycle } \\
2\end{array}$ \\
\hline $\begin{array}{l}\text { Students' interest in } \\
\text { learning }\end{array}$ & $\begin{array}{l}\text { Most of students were } \\
\text { interested in following the } \\
\text { lesson }\end{array}$ & $\begin{array}{l}\text { All of students were } \\
\text { interested in following } \\
\text { the lesson }\end{array}$ \\
\hline $\begin{array}{l}\text { Students' desire in } \\
\text { learning }\end{array}$ & $\begin{array}{l}\text { Most of students obtained } \\
\text { the reward from the } \\
\text { teacher }\end{array}$ & $\begin{array}{l}\text { All of students obtained } \\
\text { the reward from the } \\
\text { teacher }\end{array}$ \\
\hline $\begin{array}{l}\text { Students' attention in } \\
\text { learning }\end{array}$ & $\begin{array}{l}\text { Most of the students gave } \\
\text { their attention the material } \\
\text { delivered but some of } \\
\text { them still chatted with } \\
\text { their friend during } \\
\text { teaching and learning } \\
\text { process. }\end{array}$ & $\begin{array}{l}\text { Almost of the students } \\
\text { gave their attention the } \\
\text { material delivered. } \\
\text { Only few of them } \\
\text { chatted with their } \\
\text { friend. }\end{array}$ \\
\hline $\begin{array}{l}\text { Students' activeness in } \\
\text { learning }\end{array}$ & $\begin{array}{l}\text { More than half of the } \\
\text { students did discussion } \\
\text { and few of them were } \\
\text { brave to ask }\end{array}$ & $\begin{array}{l}\text { All of the } \\
\text { students did discussion } \\
\text { whit their pair and } \\
\text { many more of them } \\
\text { were brave to ask }\end{array}$ \\
\hline
\end{tabular}

\subsection{Discussion}

\subsubsection{The Progress Students' Pronunciation in Speaking}

Chen and Chung (2012) admitted that multimedia does not only brings more abundant visual and hearing enjoyment for people, but also it could be more effective than traditional teaching, it increases the interest and effectiveness of learning. They believed that multimedia teaching material breaks the traditional style of learning and thinking because learners can see words, visual aids, illustrations, and animation, which are more interesting and exciting than traditional teaching aids. 
To help students get the most out of the animation, it's important to provide tools to help them process the information and to monitor their own understanding. Such tools will be the following:

\section{Explaining Clearly the Objectives of Each Part of the Animation}

PowToon animations include many kinds of media like video songs as well as audio and visual instructions and it is the teacher's job to guide the learners before, through, and after each part of it. As a study done by Kreiner (1997) learners with guiding questions to consider while watching learned efficiently more than others.

\section{Using the Interactive Features Provided in Powtoon}

Based on a study made by Zhang (2006) and his colleges, higher level of interactivity provided through the video result in better learning efficiency on behalf of the learners. Teachers can increase the time delay of the animation between each question and answer to allow the young learners enough time for information processing or they can stop the animation and support the learners with some hints to build their confidence. Based on the result of the research and the result of the other previous research, it can be concluded that this research proved the previous research. This research tries to clarify the other previous research. The result of the current research justifies the other previous research findings; Powtoon help the students to prepare speaking pronunciation appropriately and acceptably. By early preparation, the result of the students pronunciation become more active and creative.

\subsubsection{The Students' Learning Motivation}

From the explanation above, it can be summarized that class situation was more enjoyable because the students were motivated in learning with Powtoon in several meetings. Besides, the students could respond, discuss, and practice their dialog better than before. They were actively engaged in teaching and learning process. All of the indicators of motivation in learning were improved. Therefore, it can be concluded that the students had positive attitude toward the implementation of Powtoon in teaching and learning process by increasing their motivation in learning.

\section{Conclusion}

Based on the result of the research, the researcher concludes that the activities implemented song and video conversation in Powtoon have a beneficial influence on the students' pronunciation achievement and students' learning motivation. The result of the pretest, posttest 1, and posttest 2 show that there is improvement on the students' Pronunciation. The improvement includes some difficulties of segmental features (vowels, diphthongs, and consonants) and suprasegmental features (word stress and intonation). Moreover, During the implementation of song and video using Powtoon, the students show their high learning motivation. It was seen from the students' activeness, desire, interest, and attitude.

Related to the findings above, the researcher would like to give, some suggestions in order to improve the quality of the teaching and learning process in the future. For English teachers, it issuggested to provide more speaking exercise and practice so that the students can pronounce words appropriately and acceptably. They also should be active in conducting speaking class. They need to keep their high motivation in learning English. For other researchers are suggested to use Powtoon for developing other skills such as listening, reading, and writing, find out other applications that support to improve students 
in other skills, and to develop the instruction of teaching English using Powtoon as the guided for the English teachers. Finally, it is suggested for the school or institution to take into account to teacher's and learners' need in teaching and learning process. The school or institution is suggested to provide the technology based facilities to support the teaching and learning process. Besides, the newest references also need to be provided for the teacher. Furthermore, workshop about teaching English using technology need to held in order to improve the quality of the teachers.

\section{References}

Arief S. Sadiman. (1986). Media Pendidikan Pengertian Pengembangan dan. Pemanfaatannya. Jakarta: Pustekom Dikbud dan PT. Raja. GrafindoPersada.

A.S. Hornby. (2000). Oxford Advanced Learners of Current English. New York: Oxford University Press.

Gilakjani, Abbas Pourhosein. (2012). The significant Role of Multimedia in Motivating EFL Learners' Interest in English Language Learning. International Journal of Modern Education and Computer Science, 4(4): 57- 66. Retrieved from http://search.proquest.com/docview/1627735482?accountid= 34864.

Bailey, K. M. (2005). Practical English Language Teaching: Speaking. New York: McGraw-Hill.

Brown, H. Douglas. (2007). Principles of Language Learning and Teaching. New York: Pearson Education, Inc.

Brown, H. Douglas. (2000). Teaching by Principles: An Interactive Approach to Language Pedagogy. Second Edition. New York: Pearson Education, Inc.

Bruns, Anne. (1999). Collaborative Action Research for Language Teachers. United Kingdom: Cambridge University Press.

Cameron, L. (2001). Teaching Languages to Young Learners. Cambridge: Cambridge University Press.

Clark, R. C., Mayer, R. E. (2003). E-Learning and the Science of Instruction. San Francisco: Pfeiffer.

David Hopkins. (1993). A Teacher's Guide to Classroom Research. Philadelphia. Open University Press.

Fraser, H. (2000). Coordinating Improvements in Pronunciation Teaching for Adult Learners of English as a Second Language. Canberra: DETYA Gardner, R. C., \& Lambert, W. E. (1972). Attitudes and Motivation in Second Language Learning.

Flucher, Glenn. (2003). Applied Linguistics and Language Study. United Kingdom: Pearson/ Longman.

Kelly, G. (2000). How to Teach Pronunciation. England: Pearson Education Limited Rowley, MA: Newbury House Publishers.

Harmer, Jeremy. (2007). How to Teach English. England: Pearson Education. 
Kemmis, s. \& Mc Taggart, R. (1983) The Action Research Planner. 3rd ed. Victoria, Australia: Deakin University.

Kreidler, C.W. (2004). The Pronunciation of English: A Course Book. Second Edition. Blackwell.

Kristina, Diah et. al. (2006). Pronunciation I. Surakarta: UNS Press.

Nielsen, J. (1999). Video and Streaming Media. Retrieved from www.useit.com/alertbox/video.html.

Nunan, David. (2003). Language Teaching Methodology. London. Prentice Hall International.

Noels, K. A., Clement, R., \& Pelletier, L. G. (2003). Intrinsic, Extrinsic, and Integrative Orientations of French Canadian Learners of English. The Canadian Modern Language Review, 59: 589-607.

Otis, N., Grouzet, F. M. E., \& Pelletier, L. G. (2005). Latent Motivational Change in an Academic Setting: A 3-Year Longitudinal Study. Journal of Educational Psychology, 97(2): 170-183.

Shank, P. (2005). The Value of Multimedia in Learning. PDF retrieved from http://www.adobe.com/ designcenter/thinktank/valuemedia/index.html.

Sunardi. (2004). Productive Vocabulary Mastery and Speaking Ability of The Second Year Students of MA Mu'allimin NW Pancor. In the school year 2003/2004. Selong STKIP Hamzanwadi. S-1 Thesis. Unpublished.

Suwarno, Wiji. (2006). Dasar-Dasar Ilmu Pendidikan. Jogjakarta: AR-Ruzz Media.

Ur, Penny. (1996). A Course in Language Teaching, Practice, and Theory. Cambridge: Cambridge University Press.

\section{Copyrights}

Copyright for this article is retained by the author(s), with first publication rights granted to the journal.

This is an open-access article distributed under the terms and conditions of the Creative Commons Attribution license (http://creativecommons.org/licenses/by/4.0/). 